\title{
No evidence of systematic pre-emptive loggings after notifying landowners of their lands' conservation potential
}

\author{
Eini Nieminen (1), Kalle Salovaara, Panu Halme, Janne Sakari Kotiaho
}

Received: 11 February 2020/Revised: 2 May 2020/Accepted: 2 June 2020/Published online: 23 June 2020

\begin{abstract}
Landowners can intentionally impair biodiversity values occurring on their land to pre-empt biodiversity protection. This often leads to significant negative effects on biodiversity. We studied whether landowners in Finland engaged in pre-emptive loggings after they were notified that their wooded mires are candidate sites for a mire protection program. After the notification, harvesting rates of the candidate wooded mires were significantly lower compared to harvesting rates of similar but non-candidate wooded mires. Annual and monthly harvesting rates indicated that notifying landowners of the conservation potential did not launch systematic pre-emptive logging behavior. Nevertheless, part of the candidate wooded mires were logged, so some landowners place more weight on other values than the biodiversity ones. Pre-emptive behavior has been observed in other studies suggesting that many country- or systemspecific factors such as cultural background or level of compensation can affect landowners' behavior.
\end{abstract}

Keywords Environmental policy · Forest conservation · Mire conservation · Panic clearing · Peatland .

Private protected area

\section{INTRODUCTION}

Anthropogenic activity often degrades habitats resulting in reduction or even eradication of species' populations (Newbold et al. 2015). Therefore, restrictions in land use practices are an inevitable consequence of biodiversity

Electronic supplementary material The online version of this article (https://doi.org/10.1007/s13280-020-01354-4) contains supplementary material, which is available to authorized users. protection. Land use restrictions are known to cause conflicts especially when conservation is based on commandand-control approaches such as the Endangered Species Act in the USA or the conservation program Natura 2000 in Europe. Both have been shaped with contradictions followed by for e.g., a lack of communication, information sharing, stakeholder involvement, and justice (e.g., Paavola 2003; Grodzinska-Jurczak and Cent 2011; Blicharska et al. 2016; Olive 2016). Landowners of areas hosting endangered species or habitats can have negative attitudes towards conservation actions for several reasons. For instance, land use restrictions to protect biodiversity can be considered as insulting property rights, being unfair actions, or causing economic harm (e.g., Jackson-Smith et al. 2005; Kabii and Horwitz 2006; Kamal et al. 2015; Blicharska et al. 2016; Olive 2016; Jokinen et al. 2018).

Command-and-control approaches can generate perverse incentives to intentionally destroy or damage species or habitats. Such behavior is here referred to as pre-emptive behavior. Landowners can manage their lands in ways that harm threatened species directly (Brook et al. 2003; Jokinen et al. 2018). Occurrences of threatened species can also lead to shortened rotation times of forest loggings or to an increased probability of forests becoming logged on nearby sites, thereby preventing the species from dispersing into new areas (Lueck and Michael 2003; Zhang 2004). Net reduction of forest area caused by pre-emptive behavior can also outcompete attempts to halt deforestation (Simmons et al. 2018a).

Net effects of command-and-control approaches on biodiversity have both positive and negative outcomes. The Endangered Species Act in the USA seems to protect species from extinctions and increases the likelihood of species' status to improve (Schwartz 2008), at least if species' listings to the Act are combined with sufficient 
species-specific funding (Ferraro et al. 2007; Gibbs and Currie 2012). Still, negative impacts of pre-emptive behavior on single species may be significant (Brook et al. 2003; Lueck and Michael 2003). In Australia, strict clearing bans based on the Vegetation Management Act have increased forest cover on some regions and forest types, but later changes and uncertainties in the implementation of the Act have caused pre-emptive deforestation and other perverse effects leading to a net loss of remnant forest patches (Simmons et al. 2018b).

While evidence about pre-emptive behavior comes mainly from the USA (e.g., Brook et al. 2003; Lueck and Michael 2003; Zhang 2004) and Australia (Simmons et al. 2018a, b), the topic is debated also in many other parts of the world. Increasingly more land is converted to human use and, consequently, the loss of biodiversity continues (Pereira et al. 2010; Lambin and Meyfroidt 2011; IPBES 2019). The role of private lands in biodiversity protection is increasing as these host significant proportions of distributions of many endangered species and habitats (e.g., Knight 1999; Norton 2000). It is likely that landowners in different countries may respond differently to the risk of land use restrictions caused by conservation actions. Such difference may arise due to e.g., previous environmental administrative practices or politics (Paloniemi and Vilja 2009), a cultural-specific relationship with nature and land (Silvasti 2003), or compensation practices (Byl 2019).

Establishing the European Union's Natura 2000 conservation network caused heavy opposition by local people throughout Europe (Alphandéry and Fortier 2001; Hiedanpää 2002; Paavola 2003; Grodzinska-Jurczak and Cent 2011). The opposition initiated a development towards voluntary-based conservation approaches during the 21st century (Keulartz 2009). Since then, voluntary nature protection has been a predominant tool in forest conservation in Finland, but for other habitat types similar administrative tools are still lacking (Council of State 2014; Paloniemi and Vilja 2009). In 2012, the Complementary Mire Protection Program (hereafter the CMPP) aiming to extend the national mire conservation network was politically agreed on to be based on the Nature Conservation Act (1096/1996) which allowed the CMPP to be implemented by means of land expropriations, including a full financial compensation or land exchange to landowners (Council of State 2012). The CMPP was later converted to a voluntary program, rejecting the option of expropriations (Salomaa et al. 2018; Nieminen et al. in review). However, before the rejection, landowners of mires with conservation potential were notified about the CMPP. The notification could have provoked owners of wooded mires to conduct logging in order to avoid their lands from being protected. Claims and anecdotes of such actions exist in social media sources like Twitter and forums of forestry magazines.
The aim of this paper is to determine if notifying landowners of their lands' conservation potential led to pre-emptive loggings on Finnish wooded mires. We analyzed whether harvesting rates of wooded mires chosen as candidate sites for the CMPP differed from harvesting rates of all other similar wooded mires in Finland that were not candidates for the CMPP. We also compared annual and monthly harvesting rates of mires with and without the candidate status to see whether events linked to the CMPP, such as notifying landowners of the conservation potential, caused sudden increase in the harvesting rates of the candidate wooded mires. To our knowledge, this is the first quantitative, nationwide analysis on pre-emptive behavior in Europe.

\section{MATERIALS AND METHODS}

\section{Study case}

In its preparation phase, the CMPP covered 327300 ha of unprotected candidate mires considered for protection (Alanen and Aapala 2015; Kareksela et al. 2020). The aim was to protect about 100000 ha of the ecologically most important mires to complement the existing mire protection network in Finland.

Originally in August 2012, the CMPP was politically agreed to be based on the Nature Conservation Act which enables land expropriations for conservation purposes (Council of State 2012). Practically, owners of the lands chosen for protection would have been allowed to decide whether to keep the ownership of the land, resulting in a private conservation area, or to sell it to the government. In both cases, landowners would have been compensated by being paid a market price for their land, or by exchanging their land for an equivalent parcel of the government's land elsewhere, depending on landowner's will.

The public briefing of the CMPP started in the beginning of 2013 by announcements in newspapers, a poll in a government-operated citizen portal in the internet, and hearings of stakeholder representatives. In May-July 2013, landowners of candidate mires received personal information letters notifying about field inventories that were made for the preparation of the CMPP during the summer 2013. In the autumn 2014, just before its implementation, the CMPP was revised to a voluntary program and the option of land expropriations was rejected due to political turmoil (Salomaa et al. 2018). This changed the CMPP's preparation and implementation remarkably. At that time, the CMPP provoked plenty of public deliberation. In the autumn 2015, 117000 ha of the most ecologically valuable mires were proposed to be protected, but proper administrative tools to implement their protection did not exist. 
Further political changes, such as cuts of conservation resources, left all but the government-owned proposed mires without protection. Afterwards, the CMPP has regularly appeared in the media and is mentioned also in the current Finnish Government Program (Anonymous 2019). In the current conservation policy, however, there are no signs of land expropriations being re-allowed in the CMPP.

Characteristics of wooded mires supporting their typical biodiversity features are connected to their tree stand and intact hydrological and microclimatic conditions (Laine et al. 1995; Maanavilja et al. 2014). Therefore, landowners resisting protection may easily impair conservation values of wooded mires with pre-emptive loggings. Landowners had, and still have, a possibility to log their wooded mires, since commercial forestry is legal on most of the mires considered to be included in the CMPP.

\section{Study design}

To ensure long-term effectiveness of conservation, candidate mires were planned to form hydrological entities (Aapala and Alanen 2015; Kareksela et al. 2020). Therefore, the candidate mires also included small patches of forests on mineral soils. We outlined the study to include only wooded habitat types occurring on peatlands in the boreal zone, i.e., spruce and pine mires. In Finland, both are commonly in a forestry use. For photographs of typical boreal spruce and pine mires, see Fig. S1.

We composed four groups of mires. The experimental group was composed of wooded mires with the candidate status and the control group of wooded mires without the status. Ideally, the study design would have included candidate mires of both informed and uninformed landowners, but in our real-world case all owners of candidate mires had been informed about their mires' conservation potential. Therefore, our study design was the best possible way to address the research questions.

Experimental and control groups were divided into spruce mires and pine mires. We analyzed harvesting rates during 5 years after the initial notification (2013-2017) and, additionally, stratified the data into annual and monthly harvesting rates. Concerning the monthly harvesting rates, we were especially interested in May-July 2013 when landowners received a notification of their lands being potential mires for protection, and OctoberNovember 2014 when the CMPP was revised to be a voluntary one. As a response variable for the overall harvesting rates over the 5 years and the annual harvesting rates, we calculated the area (hectares) that was logged and unlogged within each of the groups. As a response variable for the monthly harvesting rates, we utilized the number of submitted forest use notifications. We used the number rather than the hectares covered by the notifications because the sample sizes for monthly logged sites were small. In such a case the hectares might have masked the effect because an area covered by a notification varies, but a notification itself always reflects a landowner's behavior independent from the area. For figures showing the differences in the harvesting rates created according to logged area or submitted forest use notifications, see Appendix S1.

Candidate mires were mostly in a natural state or close to it. If they had been highly modified or degraded by human activity, they would not have been chosen as potential sites to the CMPP. Due to the desire to protect candidate mires as hydrological entities, some of them enclosed small degraded parts which were planned to be restored after protection. However, the average age and timber volume of candidate wooded mires likely represent those of older forests. To make the experimental and the control groups to be equivalent, we included to the analyses only those candidate and non-candidate wooded mires that were of the two most mature forest development class (advanced thinning stands and mature stands, see Appendix S2). We also calculated average diameters of trees in logged candidate and non-candidate mires and found that they did not differ remarkably, indicating that their timber quality was similar (Table S1).

We set the period of the study to be January 2013December 2017. Since the CMPP was publicly briefed from January 2013 onwards, it was not reasonable to study harvesting rates earlier. If candidate wooded mires had been logged earlier, they would not have been selected as the candidates in the first place.

In Finland, the Forest Act (1093/1996) obliges forest owners to make a notification of forest use before logging. Practically, all loggings are executed after submitting a notification, since an industrial agent such as a timber buyer or a logging planner commonly makes the notification. Illegal loggings are very rare which is verified by a well-working law enforcement (Finnish Forest Centre 2018). Therefore, we applied notifications as surrogates for the loggings.

\section{Data}

For the analyses, we compiled eight different spatial data: unlogged and logged spruce and pine mires with the candidate status, and unlogged and logged spruce and pine mires without the status (Table 1).

To compile data of all wooded mires in Finland, we utilized publicly available spatial forest resource data which include detailed information of Finnish forests (https://urly.fi/1jgz). It covers the majority of privately owned forest land but mostly it does not include government- and municipalities-owned lands (Appendix S3). However, as the majority of forest land in Finland is 
Table 1 Sample sizes of the final processed data

\begin{tabular}{|c|c|c|c|c|}
\hline Candidate status & Habitat type & Logging status & Hectares & No. of notifications \\
\hline \multirow[t]{6}{*}{ Mires with the candidate status } & \multirow[t]{3}{*}{ Spruce mires } & Unlogged & 2198 & na \\
\hline & & Logged & 183 & 235 \\
\hline & & Total & 2381 & 235 \\
\hline & \multirow[t]{3}{*}{ Pine mires } & Unlogged & 6661 & na \\
\hline & & Logged & 981 & 700 \\
\hline & & Total & 7642 & 700 \\
\hline \multirow[t]{6}{*}{ Mires without the candidate status } & \multirow[t]{3}{*}{ Spruce mires } & Unlogged & 357415 & na \\
\hline & & Logged & 78196 & 54314 \\
\hline & & Total & 435611 & 54314 \\
\hline & \multirow[t]{3}{*}{ Pine mires } & Unlogged & 599896 & na \\
\hline & & Logged & 136390 & 61473 \\
\hline & & Total & 736286 & 61473 \\
\hline
\end{tabular}

privately owned (Official Statistics of Finland 2011-2016), the data coverage can be considered representative. To restrict the data of all wooded mires to cover only advanced thinning or mature spruce and pine mire stands, we outlined the forest resource data according to a habitat type and a forest development class.

To compile data of all logged wooded mires in Finland, we utilized publicly available spatial data of forest use notifications which include information of logged forest stands (https://urly.fi/ljgF) (Appendix S3). It served as the source for all the wooded mire stands that were advanced thinning or mature ones and logged in 2013-2017. However, many of the notifications lacked information of the habitat type since it is not an obligatory field in the notification. To complete the habitat type information, we joined the notification data with the abovementioned data of all wooded mires and set the latter to act as a primary source for the habitat type. However, the data of all wooded mires did not cover all stands in the forest use notification data. We checked whether the notifications on these stands included the habitat type information, and if they did, it was used as the source for the habitat type. If the habitat type information was not available in either of the data, we excluded the stand in question from the analysis.

We detached the data of all logged wooded mires from the data of all wooded mires after which we had four data: unlogged and logged spruce and pine mires covering whole Finland.

The final eight data of unlogged and logged non-candidate and candidate spruce and pine mires were compiled by detaching the candidate spruce and pine mires from the abovementioned data of all unlogged and logged wooded mires. We made this by means of a separate data that covered locations of the CMPP's candidate sites (Alanen and Aapala 2015; Kareksela et al. 2020).

\section{Final data processing}

Assembling the datasets caused multiple fragment stands that were too small to be real forest stands. We analyzed the size distributions of the forest stand fragments separately for all eight datasets and estimated that excluding stands $\leq 0.14$ ha would reduce the number of artificial stands without eliminating many of the real small stands (Appendix S4). It is likely that we did not succeed in excluding all the artificial stands and likewise, we possibly excluded some of the existing small stands. However, we found no reason to expect any bias in the data caused by the exclusion and, therefore, consider the data to be reliable. All the data were processed with ArcMap 10.

\section{Statistical analysis}

We analyzed the harvesting rates per 5 years on mires with and without the candidate status and separately for pine and spruce mires against randomized harvesting rate distributions. To create the distributions, we set the total logged hectares of all pine and spruce mires to randomly locate on the whole area of the respective habitat. Randomization was performed with RStudio version 1.1.456 and replicated 1000 times. Replicates were compiled into a distribution describing how large proportion of logged hectares would randomly locate on the candidate mires of each habitat type. For the R-script, see Appendix S5.

\section{RESULTS}

$7.7 \%$ (183 ha) of spruce mires and $12.8 \%$ (981 ha) of pine mires with the candidate status were logged based on hectares covered with submitted forest use notifications. Respective numbers for spruce mires without the candidate 
status were $18.0 \%$ (78 $916 \mathrm{ha}$ ) and for pine mires $18.5 \%$ (136 390 ha). Therefore, the candidate mires were logged significantly less than the non-candidate ones (Fig. 1). For a map describing locations of all candidate mires and logged and unlogged wooded candidates, see Fig. S2.

Notifying landowners of their mires' conservation potential in May-July 2013 or revising the CMPP to a voluntary one in October-November 2014 did not produce harvesting peaks according to the annual harvesting rates that were calculated based on hectares covered with submitted forest use notifications (Fig. 2). In relation to the area of all candidate spruce or pine mires, the average annual harvesting rates on them were $1.54 \%$ and $2.57 \%$, respectively. On candidate spruce mires, the harvesting rate was highest in 2013 (2.03\% of all candidate spruce mires logged), whereas on pine mires, it was highest in 2016 (2.96\% of all candidate pine mires logged). Candidate
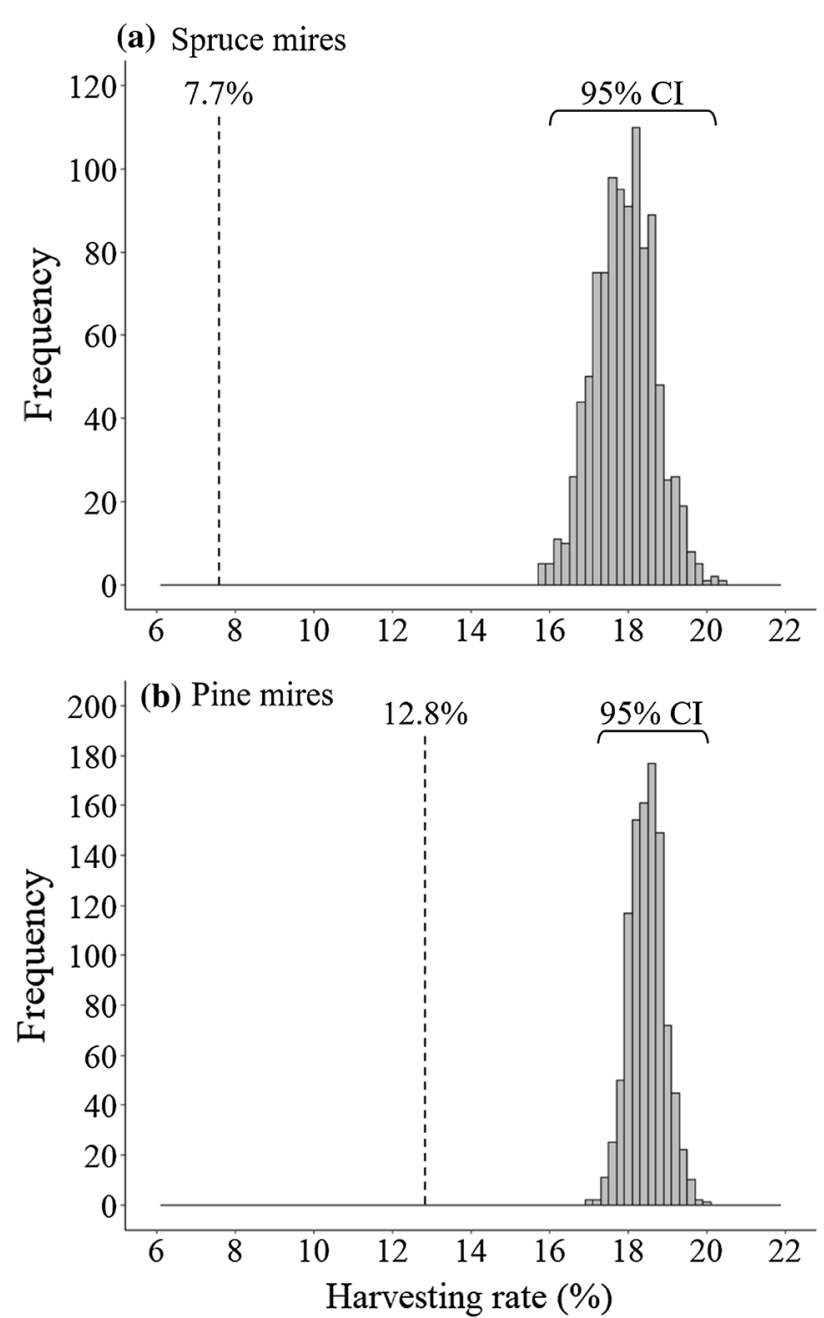

Fig. 1 Gray bars show how large proportion of logged hectares would randomly locate on candidate $\mathbf{a}$ spruce mires and $\mathbf{b}$ pine mires, when randomization is replicated 1000 times. Actual harvesting rates per 5 years on candidate mires are marked with dashed vertical lines spruce mires were logged least in $2014(0.96 \%)$ and pine mires in 2013 and 2017 (2.39\% in both years). In relation to the area of all logged wooded mires, the logged area of candidate wooded mires was very low: on candidate spruce mires it varied between 0.14 and $0.32 \%$ and on candidate pine mires between 0.60 and $0.81 \%$.

Within the years, both candidate and non-candidate mires had seasonal variation in numbers of submitted forest use notifications (Fig. 3). Notifications were submitted more in autumn and winter, and less in spring and summer. On candidate spruce mires, the highest numbers of notifications during the study period were submitted in October 2014 (11 notifications), in April 2013, and in January 2016 (9 notifications during both). Respective months and years for candidate pine mires were October 2017 (25 notifications), and October and November 2014 (24 notifications during both). Taking into account the seasonal variation, the numbers of submitted notifications did not peak in May-July 2013, when landowners were notified that their mires are candidates for the CMPP, nor in OctoberNovember 2014, when the option of land expropriations was rejected.

\section{DISCUSSION}

Our main finding was that notifying landowners of their mires' conservation potential and the possibility of mires becoming included in the CMPP did not cause systematic pre-emptive loggings. Instead, candidate wooded mires were logged significantly less than mires that were not considered for protection. The result is different from previous studies. In the USA, landowners have intentionally damaged species and habitats by applying shorter rotation times of loggings (Lueck and Michael 2003; Zhang 2004) and by changing land management practices (Brook et al. 2003). In Australia, pre-emptive behavior has caused loss of remnant forests (Simmons et al. 2018b).

While our results are encouraging, the root causes of the differences between our results and those of the earlier studies deserve further discussion. It is likely that landowners' behavior is shaped by the society they live in. Majority of Finns, regardless of their socioeconomic or demographic status, agree that protection of mire habitats and species is important (Tolvanen et al. 2013). This finding was supported also by a survey that was conducted to the citizen owners of the candidate mires during the preparation of the CMPP: almost half of the respondents had a positive attitude towards protection of their mires (Alanen and Aapala 2015). The rise of voluntary nature conservation following from Natura 2000 and other command-and-control approaches have likely helped to overcome previous biodiversity conflicts in Finland (Paloniemi 
and Vilja 2009), possibly making the public attitude receptive to new conservation initiatives. Furthermore, there is evidence that a fair conservation compensation decreases the likelihood of pre-emptive behavior and increases the likelihood of pro-conservation behavior (e.g., Langpap 2006; Ferraro et al. 2007; Byl 2019). According to Finnish legislation, landowners are eligible to a market price compensation of economic losses caused by land expropriations for biodiversity protection or for any other societally significant purposes. Hence, one reason for the lack of systematic pre-emptive behavior in our case may be that Finnish landowners perhaps do not feel their livelihood is seriously threatened by land use restrictions. In contrast, land use restrictions set e.g., by the Endangered Species Act in the USA are not compensated monetarily. Instead, if landowners pledge to certain conservation activities, they can be compensated e.g., by providing various assurances of not to set further restrictions on their land (Donahue 2005). Hence, principles of compensation are fundamentally different in Finland compared to the USA.

To determine if there were any obvious relationships between the CMPP's events and temporal patterns of the logging activity, we inspected yearly and monthly harvesting rates. The yearly harvesting rates were rather constant, but the monthly harvesting rates varied seasonally. This is explained by weather conditions favoring timber harvesting in autumn and winter when the ground is frozen and holds up forest harvesters. In May-July 2013, landowners of candidate wooded mires were notified that their mires are potential sites for protection. There was no detectable change in the monthly harvesting rates on candidate wooded mires relative to non-candidate ones, indicating that notifying landowners did not cause an increase in the logging activity. Another event potentially increasing the harvesting rates on candidate wooded mires was the decision of changing the CMPP to a voluntary program and rejecting the option of land expropriations in OctoberNovember 2014. After this, some landowners could have thought they had an opportunity to harvest without a disapproval of neighbors or the society at large (JacksonSmith et al. 2005). To some landowners, the coverage of the conflict could have served as a reminder of the CMPP's preparation, or even as a support for defiance against biodiversity protection. However, there were again no obvious change in the monthly harvesting rates on candidate wooded mires relative to non-candidate ones.

In a comparative study like ours, there is always a possibility that some other factors than the ones being explored have had an impact on the response variable. In our case, the characteristics of tree stand on candidate wooded mires and their non-candidate counterparts were similar (Table S1), but candidate wooded mires had on average higher biodiversity values since they were chosen as potential protected areas. In order to host high biodiversity, candidate wooded mires could not have been largely exposed to former land use practices such as ditching or logging since mires' typical biodiversity features are dependent on tree stand and intact hydrology (Laine et al.

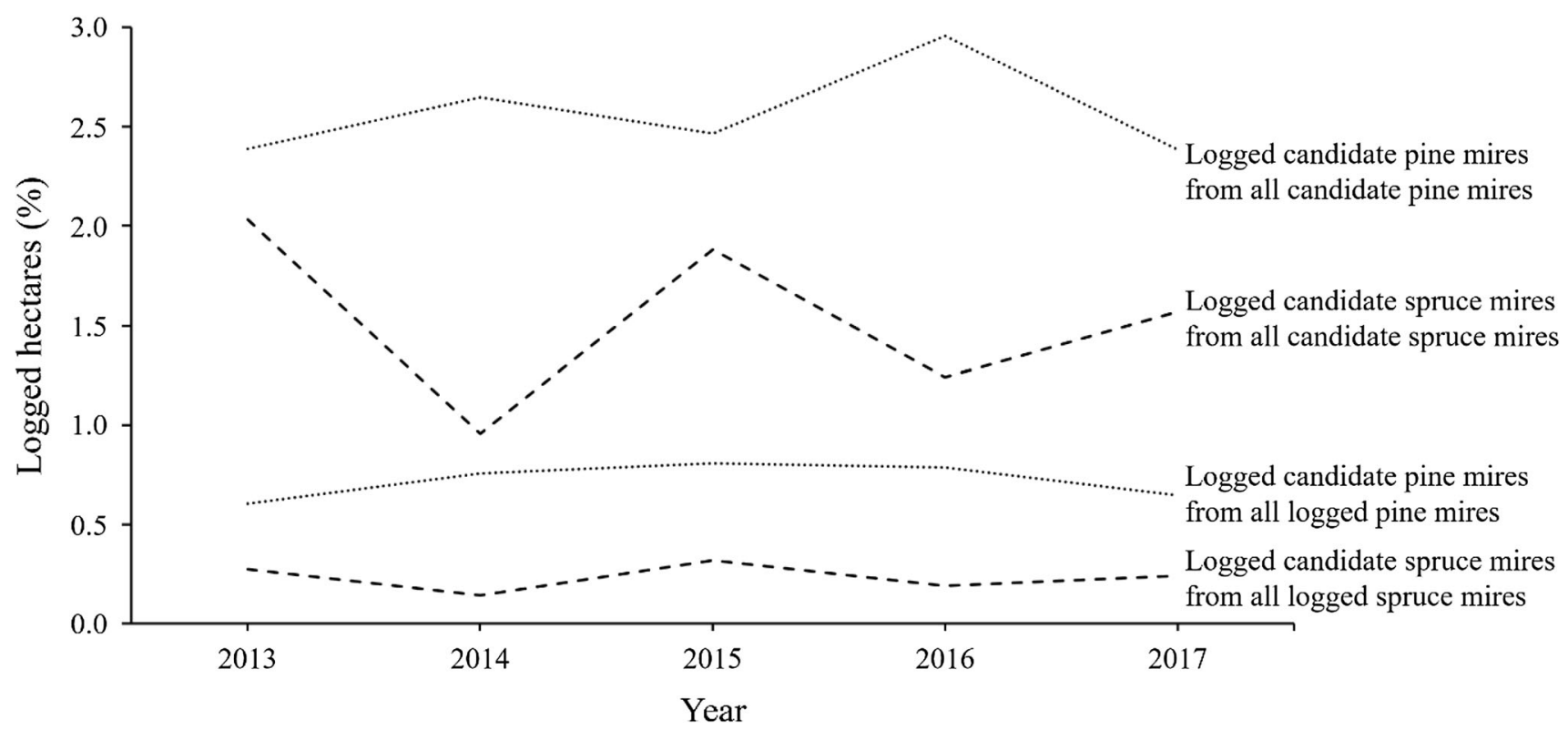

Fig. 2 Habitat-specific annual harvesting rates on candidate wooded mires calculated from all candidate wooded mires and from all logged wooded mires. Calculations of logged areas are based on hectares covered by submitted forest use notifications. Dashed lines represent spruce mires and dotted lines pine mires 
1995; Maanavilja et al. 2014). At least two factors could explain why candidate wooded mires were less exposed to land use in the first place, possibly affecting also landowners' responses to informing about their mires' conservation potential. First, it is possible that candidate wooded mires could have been on average smaller sized than non-candidate ones. This is because in the era of heavy ditching campaign in the 1960s and 1970s (Vasander 2006), large mires having a high potential for wood production or peat mining were probably more likely ditched than smaller mires. Second, it might be that candidate wooded mires locate further away from roads than their non-candidate counterparts. If candidate wooded mires were on average smaller and/or more remote than noncandidate ones, they could have been silviculturally less attractive. In Finland, however, Forestry Management Associations often endeavor to centralize loggings to certain areas so that neighboring forest properties are logged at the same time, lowering the logistical costs of smallsized regeneration ready stands. This balances the effect of possibly smaller average size of candidate wooded mires on landowners' willingness to log. Unfortunately, we were not able to calculate the areas of single candidate or noncandidate mires since their borders were lost due to the data processing (see Materials and Methods). Furthermore, over $99 \%$ of forest land in central Finland locates $<400 \mathrm{~m}$ from the nearest road (Viitala et al. 2004) and the government supports construction of new forest roads in the whole country (Temporary Act on the Financing of Sustainable
Forestry 34/2015), so it is improbable that remoteness would have prevented landowners to log their candidate wooded mires. Even if there were some other reasons for the candidate mires' low harvesting rates than landowners' awareness of their lands' conservation potential, the lack of obvious increases in the logging activity on candidate mires after notifying of their conservation value means that landowners did not engage in systematic pre-emptive loggings.

Despite the low harvesting rates, some of the candidate wooded mires were nevertheless logged in each study year. The rather constant yearly harvesting rates of candidate wooded mires, the seasonal variation in their harvesting rates imitating that of non-candidate wooded mires, and the lack of obvious logging peaks after notification letters implicate that instead of intentionally harming biodiversity values, there may have been some other reasons to log. Landowners may have simply followed their long-term logging plans that are often made in cooperation with local forestry specialists. Evidence shows that forestry-oriented landowners trust forestry specialists and prefer cooperating with them also in conservation issues rather than with environmental authorities (Paloniemi et al. 2006). Therefore, forestry-oriented landowners may have actively disregarded the information provided by the environmental authorities about their mires' high conservation potential. Such behavior may be expected particularly if a landowners' income is dependent on the actualized loggings. There is earlier evidence of Finnish forest owners
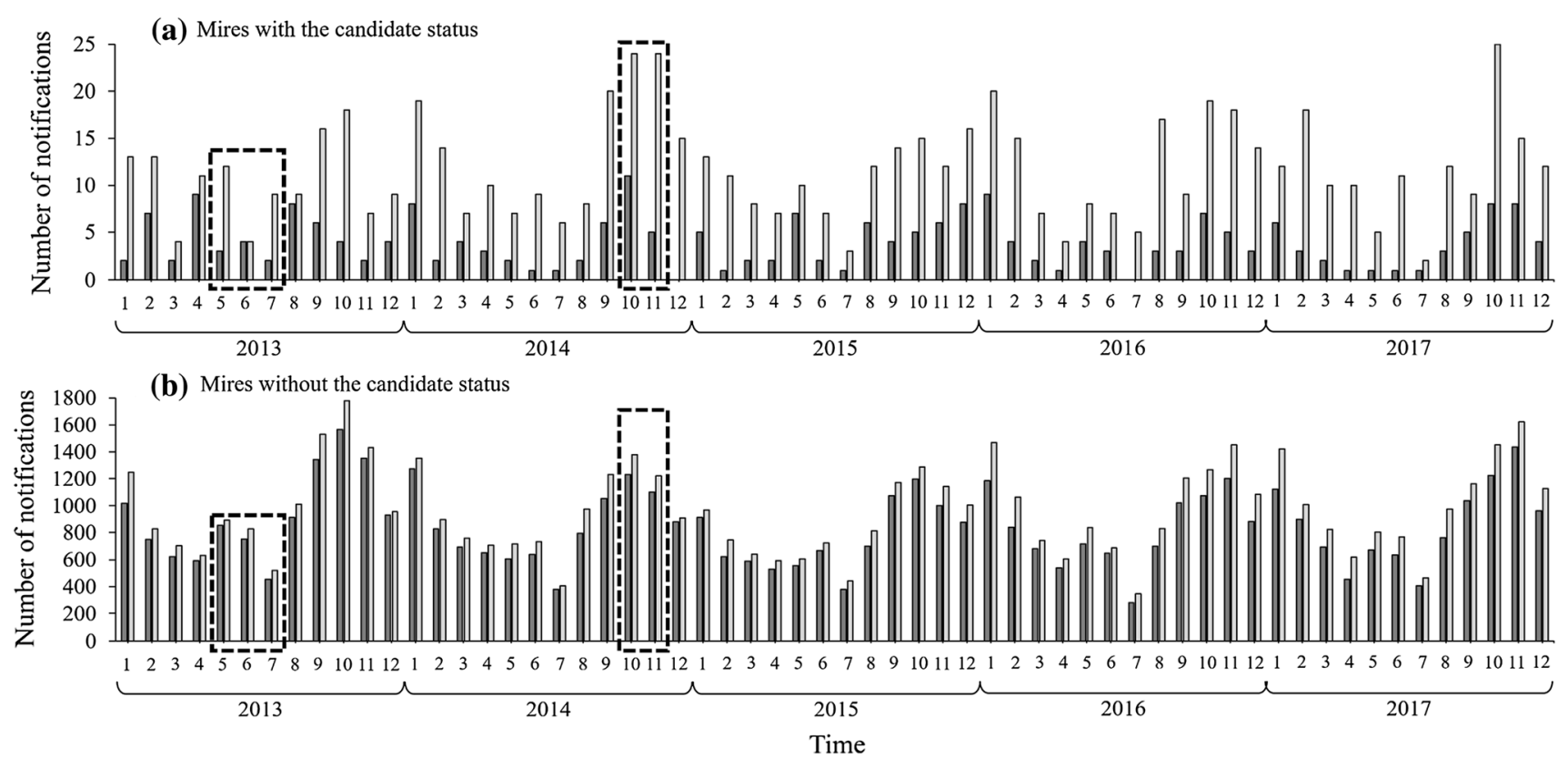

Fig. 3 Numbers of forest use notifications submitted per month in 2013-2017. Dark gray bars represent spruce mires and light gray bars pine mires. a Mires with the candidate status. b Mires without the candidate status. The boxes with dashed lines represent the months when we expected the number of notifications to rise due to the certain events concerning the CMPP 
intentionally taking actions to harm flying squirrel (Pteromys volans) (Jokinen et al. 2018), so it is also possible that some owners of candidate wooded mires executed intentional pre-emptive loggings.

Since some mire owners are conservation minded (Alanen and Aapala 2015), it might be possible that at some point, logging candidate wooded mires would reduce even without protection. However, random factors such as transferring land property to the next generation or sudden acute need of money may initiate logging of a biodiversityrich but non-protected mire even if the current owner would have decided to set the mire aside by his/her own decision. Excluding biodiversity-rich areas from official protection is a potential threat for long-term persistence of biodiversity, since forestry in Finland is so intensive that majority of forest sites will be logged when they reach maturity (Natural Resources Institute Finland 2019). If loggings on candidate wooded mires continued with the observed average annual rate of 36.6 ha $(1.54 \%)$ for spruce mires and 1962 ha $(2.57 \%)$ for pine mires, it would take only 26 and 13 years to loose half of them, respectively. Additionally, the likelihood to reach an ecologically representative mire conservation network decreases as increasingly larger area of candidate wooded mires are exposed to loggings. Originally, from 327300 ha of candidate mires, 117000 ha were proposed for protection (Alanen and Aapala 2015; Kareksela et al. 2020), leaving 210300 ha without a protection request. Revising the CMPP to a voluntary program enabled landowners to refuse protection, inevitably changing the combination of mires applicable for protection (Nieminen et al. in review). In this new situation, 210300 ha of mires originally not proposed to the CMPP could serve as compensatory sites for the mires that would be left out from protection due to some landowners' unwillingness to protect. Therefore, logging both candidate wooded mires included in and excluded from the most ecologically valuable ones is problematic.

\section{CONCLUSIONS}

Avoiding land use regulations by intentionally harming certain species or habitats has been proved to be a true phenomenon in the USA and Australia. We made the first quantitative exploration of pre-emptive behavior in Europe by studying logging behavior of landowners in Finland after they were notified that their wooded mires are candidate sites for a program that aims to extend the national mire conservation network. Unlike previous studies, we did not find evidence of systematic pre-emptive behavior. It is likely that landowners' responses to potential land use restrictions caused by biodiversity protection depend on the country- or region-specific administrative, political, and cultural circumstances such as previous experiences of biodiversity conservation or the compensation practices. It is also possible that silvicultural characteristics of wooded mires such as harvesting restricted mainly to periods of frozen ground, or on average lower value of peatland forests compared to mineral soil forests can affect landowners' behavior so that the results could have been different if the study was focused on mineral soils. Therefore, determining the exact reasons for the low harvesting rates of candidate wooded mires and the lack of systematic preemptive behavior demands further research such as mapping of landowners' attitudes, motives, and beliefs. Nevertheless, our results are encouraging in showing that informing landowners openly about their lands' conservation potential does not categorically lead to pre-empting of conservation values on wooded mires.

Acknowledgements The authors thank Dr. Anssi Lensu for counseling on data and analyses. Eini Nieminen was funded by Maj and Tor Nessling Foundation and Kone Foundation. Kalle Salovaara was funded by The Finnish Foundation for Nature Conservation. Open access funding provided by University of Jyväskylä (JYU).

Open Access This article is licensed under a Creative Commons Attribution 4.0 International License, which permits use, sharing, adaptation, distribution and reproduction in any medium or format, as long as you give appropriate credit to the original author(s) and the source, provide a link to the Creative Commons licence, and indicate if changes were made. The images or other third party material in this article are included in the article's Creative Commons licence, unless indicated otherwise in a credit line to the material. If material is not included in the article's Creative Commons licence and your intended use is not permitted by statutory regulation or exceeds the permitted use, you will need to obtain permission directly from the copyright holder. To view a copy of this licence, visit http://creativecommons. org/licenses/by/4.0/.

\section{REFERENCES}

Alanen, A., and K. Aapala. 2015. Proposal of the Mire Conservation Group for supplemental mire conservation. Reports of the Ministry of the Environment 26/2015 (in Finnish, English summary). http://hdl.handle.net/10138/158285.

Alphandéry, P., and A. Fortier. 2001. Can a territorial policy be based on science alone? The system for creating the Natura 2000 network in France. Sociologia Ruralis 41: 311-328. https://doi. org/10.1111/1467-9523.00185.

Anonymous. 2019. Inclusive and competent Finland-a socially, economically and ecologically sustainable society. Programme of Prime Minister Sanna Marin's Government 2019. Retrieved April 20, 2020, from https://valtioneuvosto.fi/en/rinne/ government-programme.

Blicharska, M., E.H. Orlikowska, J.M. Roberge, and M. GrodzinskaJurczak. 2016. Contribution of social science to large scale biodiversity conservation: A review of research about the Natura 
2000 network. Biological Conservation 199: 110-122. https:// doi.org/10.1016/j.biocon.2016.05.007.

Brook, A., M. Zint, and R. De Young. 2003. Landowners' responses to an endangered species act listing and implications for encouraging conservation. Conservation Biology 17: 1638-1649. https://doi.org/10.1111/j.1523-1739.2003.00258.x.

Byl, J.P. 2019. Perverse incentives and safe harbors in the endangered species act: Evidence from timber harvests near woodpeckers. Ecological Economics 157: 100-108. https://doi.org/10.1016/j. ecolecon.2018.11.008.

Council of State. 2012. The Government Resolution on the Sustainable Use and Protection of Peatlands. Retrieved January 15, 2012, from https://urly.fi/1mu5 (in Finnish).

Council of State. 2014. Decision in principle about continuing the program protecting biodiversity of forests in South Finland. Retrieved April 20, 2014, from https://urly.fi/1Anj (in Finnish).

Donahue, D. 2005. The Endangered Species Act and its current set of incentive tools for species protection. In Species at risk: Using economic incentives to shelter endangered species on private lands, ed. J.F. Shogren, 25-63. Austin: University of Texas Press.

Ferraro, P.J., C. Mcintosh, and M. Ospina. 2007. The effectiveness of the US endangered species act: An econometric analysis using matching methods. Journal of Environmental Economics and Management 54: 245-261. https://doi.org/10.1016/j.jeem.2007. 01.002 .

Finnish Forest Centre. 2018. Law enforcement of Forest Acts in 2018. Retrieved April 20, 2018, from https://www.metsakeskus.fi/sites/ default/files/lainvalvonta-2018.pdf (in Finnish).

Gibbs, K.E., and D.J. Currie. 2012. Protecting endangered species: Do the main legislative tools work? PLOS ONE 7: e35730. https:// doi.org/10.1371/journal.pone.0035730.

Grodzinska-Jurczak, M., and J. Cent. 2011. Expansion of nature conservation areas: Problems with natura 2000 implementation in Poland? Environmental Management 47: 11-27. https://doi. org/10.1007/s00267-010-9583-2.

Hiedanpää, J. 2002. European-wide conservation versus local wellbeing: The reception of the Natura 2000 Reserve Network in Karvia, SW-Finland. Landscape and Urban Planning 61: 113-123. https://doi.org/10.1016/S0169-2046(02)00106-8.

IPBES. 2019. Summary for policymakers of the global assessment report on biodiversity and ecosystem services of the Intergovernmental Science-Policy Platform on Biodiversity and Ecosystem Services. In ed. S. Díaz, J. Settele, E.S. Brondízio, H.T. Ngo, M. Guèze, J. Agard, A. Arneth, P. Balvanera, et al. IPBES secretariat: Bonn.

Jackson-Smith, D., U. Kreuter, and R.S. Krannich. 2005. Understanding the multidimensionality of property rights orientations: Evidence from Utah and Texas Ranchers. Society and Natural Resources 18: 587-610. https://doi.org/10.1080/ 08941920590959578.

Jokinen, M., T. Hujala, R. Paloniemi, and A. Vainio. 2018. Private landowners and protected species: What sort of noncompliance should we be worried about? Global Ecology and Conservation 15: e00407. https://doi.org/10.1016/j.gecco.2018.e00407.

Kabii, T., and P. Horwitz. 2006. A review of landholder motivations and determinants for participation in conservation covenanting programmes. Environmental Conservation 33: 11-20. https:// doi.org/10.1017/S0376892906002761.

Kamal, S., M. Kocór, and M. Grodzińska-Jurczak. 2015. Conservation opportunity in biodiversity conservation on regulated private lands: Factors influencing landowners' attitude. Environmental Science \& Policy 54: 287-296. https://doi.org/10.1016/j.envsci. 2015.07.023.

Kareksela, S., K. Aapala, A. Alanen, T. Haapalehto, J.S. Kotiaho, J. Lehtomäki, N. Leikola, N. Mikkonen, A. Moilanen, E.
Nieminen, S. Tuominen, and R. Virkkala. 2020. Combining spatial prioritization and expert knowledge facilitates effectiveness of large-scale mire protection process in Finland. Biological Conservation. https://doi.org/10.1016/j.biocon.2019.108324.

Keulartz, J. 2009. European nature conservation and restoration policy-Problems and perspectives. Restoration Ecology 17: 446-450. https://doi.org/10.1111/j.1526-100X.2009.00566.x.

Knight, R.L. 1999. Private lands: The neglected geography. Conservation Biology 13: 223-224. https://doi.org/10.1046/j.15231739.1999.013002223.x.

Laine, J., H. Vasander, and R. Laiho. 1995. Long-term effects of water level drawdown on the vegetation of drained pine mires in southern finland. Journal of Applied Ecology 32: 785-802.

Lambin, E.F., and P. Meyfroidt. 2011. Global land use change, economic globalization, and the looming land scarcity. Proceedings of the National Academy of Sciences 108: 3465-3472. https://doi.org/10.1073/pnas.1100480108.

Langpap, C. 2006. Conservation of endangered species: Can incentives work for private landowners? Ecological Economics 57: 558-572. https://doi.org/10.1016/j.ecolecon.2005.05.007.

Lueck, D., and J.A. Michael. 2003. Preemptive habitat destruction under the Endangered Species Act. The Journal of Law and Economics 46: 27-60. https://doi.org/10.1086/344670.

Maanavilja, L., K. Aapala, T. Haapalehto, J.S. Kotiaho, and E. Tuittila. 2014. Impact of drainage and hydrological restoration on vegetation structure in boreal spruce swamp forests. Forest Ecology and Management 330: 115-125. https://doi.org/10. 1016/j.foreco.2014.07.004.

Natural Resources Institute Finland. 2019. Statistics database. Age of forest stands on forest land. Retrieved November 12, 2019, from https://urly.fi/1mt3.

Newbold, T., L.N. Hudson, S.L.L. Hill, S. Contu, I. Lysenko, R.A. Senior, L. Börger, D.J. Bennett, et al. 2015. Global effects of land use on local terrestrial biodiversity. Nature 520: 45-50. https://doi.org/10.1038/nature14324.

Norton, D.A. 2000. Conservation biology and private land: Shifting the focus. Conservation Biology 14: 1221-1223.

Official Statistics of Finland 2011-2016. Ownership of Forest Land. e-publication. Helsinki: Natural Resources Institute Finland. Retrieved November 12, from https://stat.luke.fi/en/ownershipforest-land.

Olive, A. 2016. It is just not fair: The Endangered Species Act in the United States and Ontario. Ecology and Society 21: 13. https:// doi.org/10.5751/ES-08627-210313.

Paavola, J. 2003. Protected areas governance and justice: Theory and the European Union's Habitats Directive. Environmental Sciences 1: 59-77. https://doi.org/10.1076/evms.1.1.59.23763.

Paloniemi, R., I. Massa, and P. Tikka. 2006. Forest owners and official nature protection. Maaseudun uusi aika 3/2006. Retrieved April 20, 2006, from https://urly.fi/1muh (in Finnish).

Paloniemi, R., and V. Vilja. 2009. Changing ecological and cultural states and preferences of nature conservation policy: The case of nature values trade in South-Western Finland. Journal of Rural Studies 25: 87-97. https://doi.org/10.1016/j.jrurstud.2008.06. 004.

Pereira, H.M., P.W. Leadley, V. Proença, R. Alkemade, J.P.W. Scharlemann, J.F. Fernandez-Manjarréz, M.B. Araújo, P. Balvanera, et al. 2010. Scenarios for global biodiversity in the 21st century. Science 330: 1496-1501. https://doi.org/10.1126/ science. 1196624.

Salomaa, A., R. Paloniemi, and A. Ekroos. 2018. The case of conflicting Finnish peatland management-Skewed representation of nature, participation and policy instruments. Journal of Environmental Management 223: 694-702. https://doi.org/10. 1016/j.jenvman.2018.06.048. 
Schwartz, M.W. 2008. The performance of the Endangered Species Act. Annual Review of Ecology Evolution and Systematics 39: 279-299. https://doi.org/10.1146/annurev.ecolsys.39.110707. 173538.

Silvasti, T. 2003. The cultural model of "the good farmer" and the environmental question in Finland. Agriculture and Human Values 20: 143-150. https://doi.org/10.1023/A:1024021811419.

Simmons, B.A., E.A. Law, R. Marcos-Martinez, B.A. Bryan, C. McAlpine, and K.A. Wilson. 2018a. Spatial and temporal patterns of land clearing during policy change. Land Use Policy 75: 399-410. https://doi.org/10.1016/j.landusepol.2018.03.049.

Simmons, B.A., R. Marcos-martinez, E.A. Law, B.A. Bryan, and K.A. Wilson. 2018b. Frequent policy uncertainty can negate the benefits of forest conservation policy. Environmental Science \& Policy 89: 401-411. https://doi.org/10.1016/j.envsci.2018.09. 011.

Tolvanen, A., A. Juutinen, and R. Svento. 2013. Preferences of local people for the use of peatlands: The case of the richest peatland Region in Finland. Ecology and Society 18: 19. https://doi.org/ 10.5751/ES-05496-180219.

Vasander, H. 2006. The use of mires for agriculture and forestry. In Finland-land of mires, ed. T. Lindholm, and R. Heikkilä, 173-178. The Finnish Environment Institute: Helsinki. http:// hdl.handle.net/10138/37961.

Viitala, E.-J., V.-M. Saarinen, A. Mikkola, and M. Strandström. 2004. Determining construction need for forest roads by means of spatial data. Metsätieteen aikakauskirja 2/2004: 175-192 (in Finnish). http://urn.fi/URN:NBN:fi-fe2016111628790.

Zhang, D. 2004. Endangered species and Timber Harvesting-The case of red-cockaded woodpeckers. Economic Inquiry 42: 150-165. https://doi.org/10.1093/ei/cbh051.

Publisher's Note Springer Nature remains neutral with regard to jurisdictional claims in published maps and institutional affiliations.

\section{AUTHOR BIOGRAPHIES}

Eini Nieminen $(\varangle)$ graduated as a Doctor of Philosophy at the University of Jyväskylä, Finland. Her research interests include spatial conservation planning and reconciling the needs of nature and human societies.

Address: Department of Biological and Environmental Science, University of Jyväskylä, P.O. Box 35, 40014 Jyväskylä, Finland.

Address: School of Resource Wisdom, University of Jyväskylä, P.O. Box 35, 40014 Jyväskylä, Finland.

e-mail: eini.m.nieminen@jyu.fi

Kalle Salovaara graduated as a Master of Science at the University of Jyväskylä, Finland. His research interests include sustainable land use and forest management.

Address: Department of Biological and Environmental Science, University of Jyväskylä, P.O. Box 35, 40014 Jyväskylä, Finland.

e-mail: kallesalovaara94@gmail.com

Panu Halme is Senior Lecturer at the University of Jyväskylä, Finland. His research interests include the conservation ecology of several species groups in forested ecosystems, traditional rural biotopes, peatlands, and wetlands.

Address: Department of Biological and Environmental Science, University of Jyväskylä, P.O. Box 35, 40014 Jyväskylä, Finland.

Address: School of Resource Wisdom, University of Jyväskylä, P.O. Box 35, 40014 Jyväskylä, Finland.

e-mail: panu.halme@jyu.fi

Janne Sakari Kotiaho is Professor of Ecology at University of Jyväskylä, Finland. His research interests include the intersection of ecology, conservation biology and societal decision making.

Address: Department of Biological and Environmental Science, University of Jyväskylä, P.O. Box 35, 40014 Jyväskylä, Finland. Address: School of Resource Wisdom, University of Jyväskylä, P.O. Box 35, 40014 Jyväskylä, Finland.

e-mail: janne.kotiaho@jyu.fi 